\title{
KSZTAETOWANIE KLAUZUL DYSKRECJONALNYCH W SYSTEMIE DUBLIŃSKIM
}

\section{Wstęp}

Prawo azylowe stanowi ważny element polityki Unii Europejskiej. Zagadnienia dotyczące tworzenia i doskonalenia Wspólnego Europejskiego Systemu Azylowego (WESA) wielokrotnie na przestrzeni ostatnich dekad były przedmiotem prac prawodawcy europejskiego. Jednym z wypracowanych dotychczas mechanizmów w tym zakresie jest system dubliński. Mechanizm ustalania państwa odpowiedzialnego za rozpoznanie wniosku azylowego został po raz pierwszy wprowadzony do europejskiego porządku prawnego na mocy postanowień Konwencji wyznaczającej państwo odpowiedzialne za rozpatrywanie wniosków o azyl złożonych w jednym z Państw Członkowskich Wspólnot Europejskich, sporządzonej w Dublinie dnia 15 czerwca 1990 r. ${ }^{1}$ Dokument stanowił odpowiedź na niebezpiecznie nasilające się w latach 90. zjawisko tzw. „turystyki azylowej". Niezależnie od przyjętych w konwencji kryteriów ustalania państwa odpowiedzialnego za rozpoznanie wniosku o azyl, dozwolono państwom członkowskim Unii Europejskiej (UE) na rozpoznanie wniosku azylowego z pominięciem ustalonych kryteriów, a to na mocy przyznanego prawa do skorzystania z klauzul: suwerenności oraz humanitarnej. Rozwiązania

\footnotetext{
Mgr, doktorant Uniwersytetu w Białymstoku; asystent sędziego, Sąd Rejonowy w Białymstoku; e-mail: wilczynska.a.paulina@gmail.com, ORCID ID: https://orcid.org/00000003-4278-2963.

1 Konwencja wyznaczająca państwo odpowiedzialne za rozpatrywanie wniosków o azyl złożonych w jednym z Państw Członkowskich Wspólnot Europejskich, sporządzona w Dublinie dnia 15 czerwca 1990 r., Dz. U. z 2005 r. Nr 24, poz. 194 (dalej: Konwencja dublińska).
} 
klauzulowe przyjęte $\mathrm{w}$ konwencji zostały $\mathrm{w}$ prawie niezmienionej formie przeniesione do treści rozporządzenia Dublin $\mathrm{II}^{2}$, które w 2003 r. zastąpiło postanowienia dotychczasowej konwencji. $W$ nowym rozporządzeniu Dublin III ${ }^{3}$ w 2013 r. dokonano zmian mających prowadzić do wyjaśnienia pojawiających się $\mathrm{w}$ poszczególnych państwach wątpliwości interpretacyjnych $w$ tym zakresie.

Stale prowadzone badania skuteczności systemu dublińskiego skłaniają prawodawcę unijnego do kontynuowania modyfikacji, w tym także w zakresie klauzul dyskrecjonalnych, czego wyrazem są prowadzone obecnie prace nad kolejną wersją rozporządzenia - Dublin IV.

Celem badawczym niniejszego opracowania jest analiza procesu kształtowania się treści klauzul dyskrecjonalnych w systemie dublińskim, a następnie określenie roli klauzul w stosowaniu systemu.

Należy wskazać, że poza państwami członkowskimi UE system dubliński stosowany jest na podstawie odrębnych umówi międzynarodowych w Norwegii, Szwajcarii, Liechtensteinie i na Islandii ${ }^{4}$. Stosowane w treści niniejszego artykułu pojęcie „państw członkowskich" odnosi się również do wskazanych państw spoza UE.

2 Rozporządzenie Rady (WE) nr 343/2003 z dnia 18 lutego 2003 r. ustanawiające kryteria i mechanizmy określania Państwa Członkowskiego właściwego dla rozpatrywania wniosku o azyl, wniesionego w jednym z Państw Członkowskich przez obywatela państwa trzeciego, Dz. Urz. UE L 50 z 25.02.2003, s. 1-10; Dz. Urz. UE polskie wyd. spec.: rozdz. 19, t. 6, s. 109-118 (dalej: rozporządzenie Dublin II).

3 Rozporządzenie Parlamentu Europejskiego i Rady (UE) nr 604/2013 z dnia 26 czerwca 2013 r. w sprawie ustanowienia kryteriów i mechanizmów ustalania państwa członkowskiego odpowiedzialnego za rozpatrzenie wniosku o udzielenie ochrony międzynarodowej złożonego w jednym z państw członkowskich przez obywatela państwa trzeciego lub bezpaństwowca (wersja przekształcona), Dz. Urz. UE L 180 z 29.06.2013, s. 31-59 (dalej: rozporządzenie Dublin III).

4 Unia Europejska związana jest umowami o stowarzyszeniu tych państw z dorobkiem dublińskim na podstawie: umowy w sprawie stowarzyszenia Islandii i Norwegii zawartej w dniu 18 maja 1999 r.; umowy w sprawie stowarzyszenia Szwajcarii zawartej w dniu 28 lutego 2008 r.; protokołu dotyczącego stowarzyszenia Liechtensteinu zawartego w dniu 7 marca $2011 \mathrm{r}$. 


\section{Klauzula suwerenności i klauzula humanitarna w Konwencji dublińskiej i rozporządzeniu Dublin II}

Procedura ustalenia jednego państwa odpowiedzialnego za rozpoznanie wniosku azylowego na gruncie postanowień Konwencji dublińskiej, która weszła w życie 1 września 1997 r., przewidywała kryteria określenia odpowiedzialności państwa członkowskiego za rozpoznanie złożonego wniosku o udzielenie ochrony międzynarodowej. Kryteria te uszeregowane zostały według następującej hierarchii: względy rodzinne, stan posiadania dokumentu pobytu lub wizy, legalny lub nielegalny wjazd na terytorium państw członkowskich.

Każdemu z państw członkowskich przyznano oprócz powyższego prawo do skorzystania z tzw. „klauzuli suwerenności”5. Stwarzała ona możliwość przejęcia odpowiedzialności za rozpoznanie wniosku azylowego przez dane państwo członkowskie w każdej sytuacji - także wówczas, gdy nie byłoby ono za to odpowiedzialne $\mathrm{w}$ świetle podstawowych kryteriów wynikających z Konwencji dublińskiej. Warunkiem takiego przejęcia było wyrażenie zgody przez wnioskodawcę na zastosowanie tego rozwiązania. O swojej decyzji państwo takie informowało to państwo, które byłoby odpowiedzialne $\mathrm{w}$ myśl przepisów konwencji, co skutkowało zwolnieniem go z wynikających z konwencji zobowiązań (art. 3 ust. 4).

Rada Europejska już w 1997 r. uznała za istotną wadę brak wskazania skonkretyzowanych sytuacji, w których możliwe byłoby zastosowanie klauzuli suwerenności. Zaproponowano wówczas nawet stworzenie odpowiedniego katalogu przypadków, w których klauzula suwerenności mogłaby być wykorzystywana ${ }^{6}$. Stanowisko takie było niewątpliwie konsekwencją dostrzeżenia rozbieżności interpretacyjnych $\mathrm{w}$ procesie stosowania klauzuli suwerenności.

5 Commission of the European Communities, Revisiting the Dublin Convention: developing Community Legislation for Determining which Member State is Responsible for Considering an Application for Asylumsubmitted in One of the Member States, Brussels, 21.03.2000, SEC(2000)522 final, http://www.statewatch.org/semdoc/assets/files/commission/SEC-2000-522.pdf [dostęp: 7.03.2019 r.].

6 European Council on Refugees and Exiles, Position on the Implementation of the Dublin Convention in the Light of Lessons Learned from the Implementation of theSchengen Convention, 1.12.1997, par. 24-27, https:/ / www.refworld.org/pdfid/3df4d74f4.pdf [dostęp: 7.03.2019 r.]. 
Według postanowień Konwencji dublińskiej, drugim z uprawnień dyskrecjonalnych państw członkowskich była możliwość zastosowania klauzuli humanitarnej (art. 9 konwencji). Skorzystanie z tego rozwiązania mogło nastąpić w sytuacji, gdy dane państwo członkowskie nie byłoby odpowiedzialne za rozpoznanie wniosku według żadnego z kryteriów, jednak ze względów humanitarnych, w szczególności tych, które uzasadnione są sprawami rodzinnymi lub kulturowymi, powinno wniosek o azyl rozpoznać i takie jest żądanie innego państwa członkowskiego. Ostatecznym warunkiem przeniesienia odpowiedzialności za rozpoznanie wniosku była zgoda państwa, do którego skierowano żądanie w tym przedmiocie.

Porównawcza analiza obydwu klauzul nasuwa konkluzję, że jedyną wprost wyartykułowaną różnicą między tymi uregulowaniami jest strona inicjująca skorzystanie $\mathrm{z}$ nich. O ile bowiem w przypadku klauzuli suwerenności przejęcie odpowiedzialności odbywa się z inicjatywy państwa, które chce zająć się rozpoznaniem wniosku, a nie jest za to odpowiedzialne $\mathrm{z}$ mocy postanowień konwencji, o tyle klauzulę humanitarną można zastosować, gdy to państwo odpowiedzialne uzasadni na życzenie wnioskodawcy, że z powodów humanitarnych lepiej dla wnioskodawcy będzie, gdy jego wniosek azylowy zostanie rozpoznany przez inne państwo członkowskie, choć nie wynika to z ustalonych konwencją kryteriów. Pozostałe warunki skorzystania z klauzul konwencja pozostawiła do interpretacji samych państw członkowskich.

Postanowienia Konwencji dublińskiej zostały z dniem 17 marca 2003 r. zastąpione treścią rozporządzenia Dublin II, które zostało skonstruowane $\mathrm{w}$ odpowiedzi na dostrzeżone problemy powstałe $\mathrm{w}$ czasie stosowania konwencji.

We wniosku dotyczącym rozporządzenia Dublin II z dnia 26 lipca 2001 r. określono klauzulę suwerenności jako instrument do uwzględniania przy ustalaniu państwa członkowskiego odpowiedzialnego za rozpoznanie wniosku azylowego względów o znaczeniu politycznym, humanitarnym, ale też czysto praktycznym, w sytuacji gdy są one istotne dla danego państwa członkowskiego, a nie byłyby brane pod uwagę przy wykorzystaniu podstawowych kryteriów. Europejski Urząd Statystyczny nie dysponuje danymi dotyczącymi wykorzystania klauzuli suwerenności w okresie stosowania Konwencji dublińskiej i rozporządzenia Dublin II. 
Z kolei uzasadniając przeniesienie klauzuli humanitarnej do rozporządzenia Dublin II, komisja we wniosku wskazała, że klauzula ta służy głównie temu, by zapobiegać i odwracać negatywne skutki rozłączenia rodzin, do którego mogłoby dochodzić w razie zastosowania podstawowych kryteriów. Przywoływano przy tym istnienie interesu zarówno państw członkowskich, jak i samych wnioskodawców ${ }^{7}$.

W rozporządzeniu Dublin II dokonano jednak uzupełnienia przypadków zastosowania klauzuli humanitarnej poprzez wyliczenie i doprecyzowanie przyczyn humanitarnych w art. 15 ust. 2 rozporządzenia:

w przypadku, gdy zainteresowana osoba jest uzależniona od pomocy innej osoby, z powodu ciąży lub opieki nad niemowlęciem, poważnej choroby, poważnego upośledzenia lub podeszłego wieku, Państwa Członkowskie nie rozłączają lub łączą osoby ubiegające się o azyl z osobą spokrewnioną przebywającą na terytorium jednego z Państw Członkowskich, pod warunkiem, że więzy rodzinne istniały w kraju pochodzenia ${ }^{8}$.

Poniżej zaprezentowano wyniki analizy danych dotyczących korzystania z klauzuli humanitarnej na gruncie rozporządzenia Dublin II za okres od 2008 do 2013 r.

7 Commission of the European Communities, Proposal for a Council Regulation Establishing the Criteria and Mechanisms for Determining the Member State Responsible for Examining an Asylum Application Lodged in One of the Member States by a Third-Country National, Brussels, 26.07.2001, COM(2001) 447 final, http:/ / ec.europa.eu/transparency/regdoc/rep/1/2001/EN/1-2001-447-EN-F1-1.Pdf [dostęp: 11.03.2019 r.].

8 Tamże, poz. 41-48. 
Tabela 1. Stosowanie klauzuli humanitarnej w latach 2008-2013 względem liczby wszystkich złożonych wniosków o azyl

\begin{tabular}{|c|c|c|c|}
\hline & $\begin{array}{l}\text { Ogólna liczba } \\
\text { wszczętych } \\
\text { postępowań } \\
\text { wstępnych }\end{array}$ & $\begin{array}{c}\text { Liczba złożonych } \\
\text { wniosków o przejęcie } \\
\text { z powołaniem } \\
\text { na klauzulę } \\
\text { humanitarną }\end{array}$ & $\begin{array}{c}\text { Odsetek przypadków } \\
\text { skorzystania } \\
\text { z klauzuli } \\
\text { humanitarnej }\end{array}$ \\
\hline Słowacja & 3900 & 33 & $0,85 \%$ \\
\hline Słowenia & 1605 & 10 & $0,62 \%$ \\
\hline Czechy & 5840 & 24 & $0,41 \%$ \\
\hline Grecja & 73195 & 274 & $0,37 \%$ \\
\hline Polska & 58520 & 114 & $0,19 \%$ \\
\hline Rumunia & 8745 & 16 & $0,18 \%$ \\
\hline Litwa & 3035 & 4 & $0,13 \%$ \\
\hline Finlandia & 20885 & 23 & $0,11 \%$ \\
\hline Bułgaria & 12045 & 13 & $0,11 \%$ \\
\hline Węgry & 32675 & 34 & $0,10 \%$ \\
\hline Szwajcaria & 121165 & 123 & $0,10 \%$ \\
\hline Irlandia & 11660 & 9 & $0,08 \%$ \\
\hline Holandia & 87230 & 53 & $0,06 \%$ \\
\hline Belgia & 143875 & 43 & $0,03 \%$ \\
\hline Niemcy & 365655 & 99 & $0,03 \%$ \\
\hline Szwecja & 208585 & 48 & $0,02 \%$ \\
\hline Cypr & 14655 & 3 & $0,02 \%$ \\
\hline Hiszpania & 20730 & 4 & $0,02 \%$ \\
\hline Malta & 11615 & 2 & $0,02 \%$ \\
\hline Włochy & 142050 & 24 & $0,02 \%$ \\
\hline Norwegia & 72120 & 8 & $0,01 \%$ \\
\hline Austria & 88875 & 9 & $0,01 \%$ \\
\hline Wielka Brytania & 142300 & 14 & $0,01 \%$ \\
\hline Francja & 327220 & 12 & $0,00 \%$ \\
\hline
\end{tabular}

Źródło: opracowanie własne na podstawie danych dostępnych na portalu internetowym Europejskiego Urzędu Statystycznego z dnia 11.03.2019 r.

Dostępne dane statystyczne pozwoliły na wyliczenie odsetku przypadków stosowania klauzuli humanitarnej w badanym okresie. Z przeprowadzonych analiz wynika, że w latach 2008-2013 klauzula humanitarna w znikomym procencie wykorzystywana była przez państwa 
członkowskie. Dane uwzględniają jedynie te państwa, w których w badanym okresie państwo członkowskie złożyło wniosek o przejęcie powołując się na klauzulę humanitarną więcej niż jeden raz. Jak widać, w latach 2008-2013 taka sytuacja miała miejsce w 24 państwach członkowskich. Z objętych badaniem państw, największy odsetek powołań na klauzulę humanitarną odnotowano na Słowacji, najmniejszy zaś we Francji. W żadnym państwie odsetek ten nie przekroczył jednak 1\% wszystkich rozpatrywanych przypadków. Biorąc pod uwagę charakter przyznanych państwom uprawnień dyskrecjonalnych, które w praktyce powinny stanowić jedynie wyjątek od stosowania podstawowych kryteriów przyjętych $\mathrm{w}$ rozporządzeniu, tak znikoma liczba przypadków sięgania po to uprawnienie wydaje się być zgodna $z$ intencją prawodawcy. Inny wniosek nasuwa się jednak po dokonaniu analizy zaprezentowanych powyżej danych w kontekście orzecznictwa dotyczącego tej materii.

Należy bowiem zauważyć, że wobec dużej dowolności interpretacyjnej, stosowanie klauzul niewątpliwie mogło powodować istotne zagrożenia skuteczności całego systemu dublińskiego. Przez poziom skuteczności rozumieć należy w tym wypadku stopień osiągnięcia celu, dla jakiego system został stworzony (szybkie ustalenie państwa odpowiedzialnego za rozpoznanie wniosku azylowego i zapobieganie równorzędnemu składaniu wielu wniosków w rożnych państwach członkowskich). Istniało też zagrożenie w postaci znacznego wydłużenia całej procedury azylowej wobec przedłużania się procedury wstępnej rozpatrywania wniosku opartej o system dubliński. Samo już bowiem skierowanie żądania przejęcia wniosku do rozpoznania na podstawie klauzuli humanitarnej, czy wyrażenie woli przejęcia wniosku do rozpoznania na podstawie klauzuli suwerenności, może powodować znaczny chaos prawny i faktyczny z uwagi na wątpliwości interpretacyjne. Warto zauważyć, że ani Konwencja dublińska, ani późniejsze rozporządzenie Dublin II nie przewidywały osobnych mechanizmów rozstrzygania sporów kompetencyjnych w zakresie klauzul dyskrecjonalnych. To $\mathrm{z}$ kolei groziło wydłużeniem postępowania i tym samym utrzymywaniem „w niepewności” osób, które złożyły wniosek o azyl.

Powyższe znajduje odzwierciedlenie w orzecznictwie Trybunału Sprawiedliwości Unii Europejskiej (TSUE). Przykładowo w wyroku z dnia 6 listopada 2012 r. wydanym w sprawie C-245/119 trybunał rozstrzy-

9 Wyrok TSUE z dnia 6 listopada 2012 r. wydanym w sprawie C-245/11, ECLI:EU:C:2012:685. 
gał $\mathrm{w}$ ramach zadanego przez organ austriacki pytania prejudycjalnego o wykładni przepisów rozporządzenia dotyczących klauzuli suwerenności oraz klauzuli humanitarnej. W wydanej przez Rzecznika Generalnego opinii z dnia 27 czerwca 2012 r. zreferowano stanowiska poszczególnych państw członkowskich co do wskazanej sprawy ${ }^{10}$. Zdania co do sposobu wykładni klauzuli humanitarnej i suwerenności były według tejże opinii stanowczo podzielone. Warto zauważyć w tym miejscu, że wniosek o wydanie orzeczenia $\mathrm{w}$ trybie prejudycjalnym złożony został $\mathrm{w}$ dniu 23 maja 2011 r., zaś TSUE ostatecznie wydał orzeczenie $\mathrm{w}$ dniu 6 listopada 2012 r., a zatem postępowanie $\mathrm{w}$ tej sprawie trwało półtora roku. W tym czasie wnioskodawca - podmiot postępowania prejudycjalnego oczekiwał „w niepewności” ciągle na etapie wstępnej oceny wniosku bez jego merytorycznej analizy.

Słusznym, w perspektywie przytoczonego orzeczenia, które odzwierciedla ogólną tendencję, wydaje się wniosek, że korzystanie z klauzul dyskrecjonalnych w czasie stosowania rozporządzenia Dublin II w praktyce dostarczało wątpliwości interpretacyjnych, powodujących konieczność zaangażowania TSUE, a w konsekwencji prowadziło do istotnego przedłużenia procedury wstępnej. Negatywne skutki stale powstających wątpliwości zniechęcały państwa członkowskie do korzystania z przyznanych uprawnień dyskrecjonalnych, co potwierdza wynik przeprowadzonego badania danych statystycznych w zakresie stosowania klauzuli humanitarnej. Niewątpliwie był to impuls do udoskonalenia przepisów w omawianym zakresie.

\section{Klauzule dyskrecjonalne w rozporządzeniu Dublin III}

Dając wyraz walce z zaobserwowanymi nieprawidłowościami, Komisja Europejska w dniu 3 grudnia 2008 r. przedstawiła wniosek dotyczący reformy rozporządzenia Dublin $\mathrm{II}^{11}$. Zaproponowane we wniosku

10 Opinia Rzecznika Generalnego Vericy Trstejnak przedstawiona w dniu 27 czerwca 2012 r., Sprawa C-241/11, ECLI:EU:C:2012:389, http://curia.europa.eu/juris/document $/$ document.jsf?text $=\&$ docid $=128441 \&$ pageIndex $=0 \&$ doclang=pl\&mode=lst\&dir=\&o cc=first\&part=1\&cid=3600657 [dostęp: 11.03 .2019 r.].

11 Komisja Wspólnot Europejskich, Wniosek rozporządzenie Parlamentu Europejskiego i Rady ustanawiające kryteria i mechanizmy ustalania państwa członkowskiego 
rozwiązania wyszły naprzeciw sygnalizowanym wcześniej problemom niejasności przepisów i zagrożenia przedłużaniem się procedury wstępnej $\mathrm{w}$ razie wszczęcia postępowania o zastosowanie którejś z klauzul. Nastąpiła wówczas rewizja uprawnień dyskrecjonalnych, zaś regulacje ich dotyczące objęto jednym rozdziałem. Uznano bowiem, że zarówno klauzula suwerenności, jak i dyskrecjonalna - stanowiące wyjątki od kryteriów ogólnych - dla optymalizacji systematyki aktu winny znajdować się w jednym rozdziale. Dokonano wyjaśnienia procedur ich stosowania. Skróceniu do dwóch miesięcy względem poprzedniego rozwiązania uległ termin na udzielenie odpowiedzi w wypadku wszczęcia procedury zastosowania klauzuli humanitarnej. Dodatkowo mechanizm rozstrzygania sporów rozszerzony został do sporów związanych ze stosowaniem klauzul. Rozwiązania te w dużej mierze wykorzystane zostały w wydanym rozporządzeniu Dublin III.

Rzecznik Generalny Paolo Mengozzi w opinii do sprawy TSUE C-57/16 z dnia 25 lipca 2018 r. zwrócił uwagę na wyjaśnienie zawarte w rozporządzeniu Dublin III dotyczące charakteru klauzuli suwerenności. Zauważył bowiem, że brzmienie art. 17 ust. 1 akapit pierwszy rozporządzenia Dublin III, zawiera istotną różnicę względem poprzedniej regulacji, która to różnica sprowadza się do zastąpienia wyrażenia „może rozpatrzyć” sformułowaniem „może zdecydować o rozpatrzeniu”. Ta modyfikacja treści klauzuli suwerenności powtarza się w akapicie drugim art. 17 ust. 1 rozporządzenia Dublin III, który stanowi, że „państwo członkowskie, które zdecydowało się rozpatrzyć wniosek o udzielenie ochrony międzynarodowej na mocy niniejszego ustępu, staje się odpowiedzialnym państwem członkowskim". Dodatkowo rzecznik podkreślił, że dodany w rozporządzeniu Dublin III akapit trzeci art. 17 ust. 1 przewiduje, że „państwo członkowskie, które przystępuje do rozpatrzenia wniosku o udzielenie ochrony międzynarodowej, zobowiązane jest do zaznaczenia w systemie Eurodac zgodnie z rozporządzeniem nr 603/2013 daty wydania decyzji o rozpatrzeniu wniosku". Tego rodzaju zmiany czynią zdaniem rzecznika zadość zamiarowi sformalizowania procedury korzystania z klauzuli

odpowiedzialnego za rozpatrzenie wniosku o udzielenie ochrony międzynarodowej złożonego w jednym z państw członkowskich przez obywatela kraju trzeciego lub bezpaństwowca (wersja przekształcona), Bruksela, 3.12.2008, KOM(2008) 820 wersja ostateczna, https:/ / eur-lex.europa.eu/legal-content/PL/TXT/?qid=1550668055377\&uri=CELEX:520 08PC0820 [dostęp: 20.02.2019 r.]. 
suwerenności i wyjaśnienia przypadków jej zastosowania. Ma to również na celu zapobieganie wykorzystywaniu wielu procedur rozpatrzenia wniosku, co byłoby czynnikiem powodującym nieskuteczność systemu dublińskiego ${ }^{12}$.

Jak wskazuje B. Kowalczyk, prawodawca na kanwie wypracowanych w drodze orzecznictwa wniosków skłania się obecnie ku empirycznemu podejściu do klauzuli suwerenności. Charakteryzuje się ono obowiązkiem dokonywania analizy czynników, które pozostają poza kryteriami ustalania państwa odpowiedzialnego za rozpoznanie wniosku azylowego oraz obowiązkiem precyzyjnego określania powodów, dla których nie zastosowano uprawnienia dyskrecjonalnego ${ }^{13}$. W orzeczeniu TSUE z dnia 21 grudnia 2011 r. wydanym w sprawach połączonych C-411/10 i C-493/10 dokonano interpretacji przepisów dotyczących klauzuli suwerenności w duchu ograniczenia dyskrecjonalnego uprawnienia państw do przejęcia wniosku o azyl do rozpoznania. Ustalono bowiem, że decyzji w tym zakresie nie pozostawia się zupełnie swobodnie woli państwa i reżimowi krajowemu, ponieważ sama możliwość jej podjęcia stanowi część mechanizmu przyjętego w rozporządzeniu Dublin III jako akcie prawa unijnego ${ }^{14}$.

Zaprezentowane poniżej statystyki obejmują dane dotyczące liczby wniosków złożonych w latach 2014-2017, w zestawieniu z danymi odnoszącymi się do liczby wydanych decyzji jednostronnych o zastosowaniu klauzuli suwerenności.

12 Opinia Rzecznika Generalnego Paola Mengozziego przedstawiona w dniu 25 lipca 2018 r., Sprawa C-56/17 Bahtiyar Fathi przeciwko Predsedatel na Darzhavna agentsia za bezhantsite, poz. 28, ECLI:EU:C:2018:621, http://curia.europa.eu/juris/document/document.jsf?text=klauzula*\%2Bsuwerenno $\% 25$ C5\%259Bci*\%2Bhumanitarna*\&docid=2044 $21 \&$ pageIndex $=0 \&$ doclang $=$ pl\&mode $=$ req \&dir $=\& o c c=$ first $\&$ part $=1 \& c i d=3303256 \#$ ct $x 1$ [dostęp: 11.03.2019 r.].

13 Zob. B. Kowalczyk, Kompetencje dyskrecjonalne państw w podstawach systemu dublinskiego, Acta Universitatis Wratislaviensis. Prawo 2015, nr 317, s. 94.

14 Zob. wyrok TSUE z dnia 21 grudnia 2011 r. wydany w sprawach połączonych C-411/10 i C-493/10, ECLI:EU:C:2011:865. 
Tabela 2. Sprawy, w których państwa członkowskie wydały jednostronne decyzje o skorzystaniu z klauzuli suwerenności na tle wszystkich postępowań wstępnych w latach 2014-2017

\begin{tabular}{|l|c|c|c|c|}
\hline & 2014 & 2015 & 2016 & 2017 \\
\hline $\begin{array}{l}\text { Liczba wniosków złożonych } \\
\text { w poszczególnych } \\
\text { państwach członkowskich }\end{array}$ & 640970 & 1393920 & 1293265 & 735430 \\
\hline $\begin{array}{l}\text { Liczba jednostronnych decyzji o przejęciu } \\
\text { wniosku azylowego z uwagi na klauzule } \\
\text { suwerenności }\end{array}$ & 3917 & 11651 & 41853 & 9508 \\
\hline $\begin{array}{l}\text { Procent wszystkich wydanych } \\
\text { decyzji jednostronnych }\end{array}$ & $0,61 \%$ & $0,84 \%$ & $3,24 \%$ & $1,29 \%$ \\
\hline
\end{tabular}

Źródło: opracowanie własne na podstawie danych dostępnych na portalu internetowym Europejskiego Urzędu Statystycznego z dnia 11.03.2019 r.

$\mathrm{Z}$ analizy przygotowanego zestawienia statystycznego odnoszącego się do klauzuli suwerenności wynika wzrost przypadków wydawania decyzji jednostronnych w przedmiocie przejęcia wniosku do rozpoznania w drodze skorzystania z klauzuli suwerenności w latach 2014-2016. Szczególnie widoczne jest to w przypadku porównania 2015 i 2016 r. W 2017 r. odnotowano zaś spadek przypadków wydawania decyzji jednostronnych $\mathrm{w}$ tym zakresie. $\mathrm{W}$ dalszym ciągu liczba ta utrzymuje się na poziomie powyżej $1 \%$. Przyczyną wzrostu mogą być prace nad eliminowaniem wątpliwości interpretacyjnych, prowadzone $\mathrm{w}$ toku stosowania rozporządzenia Dublin III w drodze wydawania orzeczeń mających na celu wyjaśnienie pojawiających się wątpliwości. Dalsza szczegółowa analiza danych udostępnionych przez Europejski Urząd Statystyczny wykazała, że we wszystkich badanych latach znakomitą większość przypadków zastosowania klauzuli suwerenności odnotowano w Niemczech - odpowiednio w kolejnych latach aż 56,80\%,90,08\%, 94,77\% i 69,39\% wszystkich wydanych w państwach członkowskich decyzji jednostronnych. Taki stan rzeczy obrazuje kształt prowadzonej w tych latach w Niemczech polityki azylowej, która ewidentnie nastawiona była na przyjmowanie uchodźców, głównie z powodów o podłożu demograficznym czy ekonomicznym ${ }^{15}$. Świadczy to również o tym, że wiele osób składających wnioski o azyl w UE mogło

15 Szerzej zob. P. Kowalewski, Ekonomiczna kalkulacja, czyli dlaczego Niemcy tak chętnie przyjmują uchodźców [online], serwis internetowy Forsal.pl, 14.12.2015 r., https://forsal.pl/ artykuly/910358, imigranci-w-niemczech-starzenie-sie-spoleczenstwa-demografia-uchodzcy.html [dostęp: 15.03.2019 r.]. 
wykazać się swego rodzaju powiązaniami z państwem niemieckim, co uzasadniało wydanie przedmiotowych decyzji. $Z$ kolei żadne z pozostałych państw członkowskich nie przekroczyło w żadnym $\mathrm{z}$ badanych lat 10\% przypadków wszystkich wydanych w UE decyzji jednostronnych. Dodatkowo z dostępnych danych wynika, że z możliwości wydania takiej decyzji nie skorzystało w ogóle: w latach 2014-2015 - 7 państw, zaś w latach 2016 i 2017 odpowiednio - 12 i 8 państw członkowskich (przy czym dane nie obejmują wszystkich państw członkowskich).

$\mathrm{W}$ analizowanym okresie wzrost można zaobserwować $\mathrm{w}$ przypadku stosowania klauzuli humanitarnej (art. 17 ust. 2 rozporządzenia Dublin III).

Tabela 3. Odsetek spraw, w których państwa członkowskie zwróciły się do innych państw członkowskich o przejęcie wniosku do rozpoznania w myśl klauzuli humanitarnej w latach 2014-2017

\begin{tabular}{|c|c|c|c|c|c|c|c|c|c|c|c|c|}
\hline & \multicolumn{3}{|c|}{2014} & \multicolumn{3}{|c|}{2015} & \multicolumn{3}{|c|}{2016} & \multicolumn{3}{|c|}{2017} \\
\hline &  & 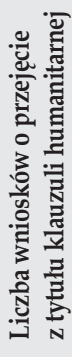 &  & 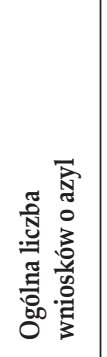 & 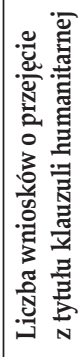 & 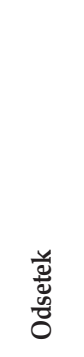 &  & 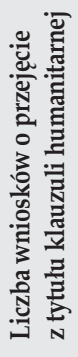 &  & 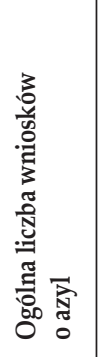 & 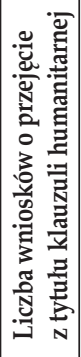 & 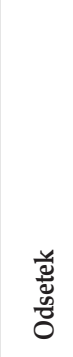 \\
\hline Belgia & 22710 & 4 & $0,02 \%$ & 44660 & 1 & 每, & 18280 & 15 & $0,08 \%$ & 18340 & 6 & $0,03 \%$ \\
\hline Bułgar & 11080 & 0 & $0,00 \%$ & 20390 & 1 & $000 \%$ & 19420 & bd & 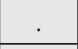 & 3695 & 21 & $0,57 \%$ \\
\hline Czechy & 1145 & $b d$ & & 1515 & $\mathrm{bd}$ & & 1475 & $\mathrm{bd}$ & 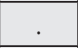 & 1445 & $\mathrm{bd}$ & \\
\hline Dania & 14680 & 2 & $0,01 \%$ & 20935 & 3 & $0,01 \%$ & 6180 & 146 & $2,36 \%$ & 3220 & 19 & $0,59 \%$ \\
\hline Niemcy & 202645 & 37 & $0,02 \%$ & 476510 & 14 & $0,00 \%$ & 745155 & 48 & $0,01 \%$ & 222560 & 88 & $0,04 \%$ \\
\hline Estonia & 155 & 0 & $0,00 \%$ & 230 & 0 & $0,00 \%$ & 175 & 0 & $0,00 \%$ & 190 & 0 & $0,00 \%$ \\
\hline Irlandia & 1450 & 4 & $0,28 \%$ & 3275 & 1 & $0,03 \%$ & 2245 & 0 & $0,00 \%$ & 2930 & 1 & $0,03 \%$ \\
\hline Grecja & 9430 & 154 & $1,63 \%$ & 13205 & 124 & $0,94 \%$ & 51110 & 362 & $0,71 \%$ & 58650 & 1471 & $2,51 \%$ \\
\hline Hiszpania & 5615 & $\mathrm{bd}$ &  & 14780 & $\mathrm{bd}$ & & 15755 & 0 & $0,00 \%$ & 36605 & 0 & $0,00 \%$ \\
\hline Francja & 64310 & 1 & $0,00 \%$ & 76165 & 0 & $0,00 \%$ & 84270 & 8 & $0,01 \%$ & 99330 & 36 & $0,04 \%$ \\
\hline Chorwacja & 450 & 0 & $0,00 \%$ & 210 & 1 & $0,48 \%$ & 2225 & 6 & $0,27 \%$ & 975 & 1 & $0,10 \%$ \\
\hline Włochy & 64625 & 0 & $0,00 \%$ & 83540 & 0 & $0,00 \%$ & 122960 & 6 & $0,00 \%$ & 128850 & 13 & $0,01 \%$ \\
\hline Cypr & 1745 & $\mathrm{bd}$ & & 2265 & $\mathrm{bd}$ & & 2940 & $\mathrm{bd}$ & . & 4600 & 14 & $0,30 \%$ \\
\hline Łotwa & 375 & 0 & $0,00 \%$ & 330 & 0 & $0,00 \%$ & 350 & 1 & $0,29 \%$ & 355 & 0 & $0,00 \%$ \\
\hline Litwa & 440 & $\mathrm{bd}$ & & 315 & $\mathrm{bd}$ & . & 430 & 0 & $0,00 \%$ & 545 & 2 & $0,37 \%$ \\
\hline Luksemburg & 1150 & 0 & $0,00 \%$ & 2505 & 1 & $0,04 \%$ & 2160 & 0 & $0,00 \%$ & 2430 & 2 & $0,08 \%$ \\
\hline
\end{tabular}




\begin{tabular}{|c|c|c|c|c|c|c|c|c|c|c|c|c|}
\hline & \multicolumn{3}{|c|}{2014} & \multicolumn{3}{|c|}{2015} & \multicolumn{3}{|c|}{2016} & \multicolumn{3}{|c|}{2017} \\
\hline & 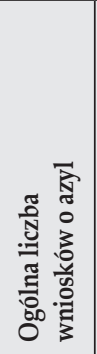 & 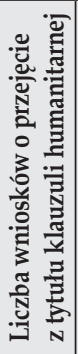 & 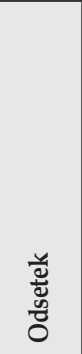 & 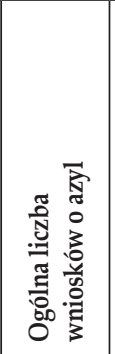 & 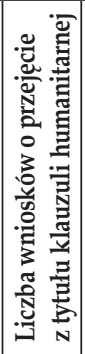 & $\begin{array}{l}\frac{y}{ \pm ٍ ~} \\
\frac{\mathscr{D}}{0}\end{array}$ & 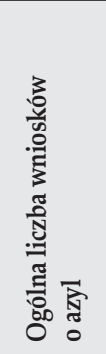 &  & 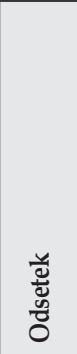 & 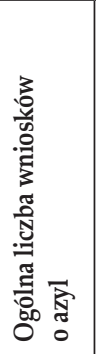 &  & 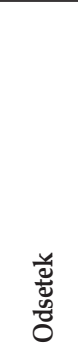 \\
\hline Węgry & 42775 & 9 & $0,02 \%$ & 177135 & $\mathrm{bd}$ & . & 29430 & $b d$ & . & 3390 & 4 & $0,12 \%$ \\
\hline Malta & 1350 & 0 & $0,00 \%$ & 1845 & 0 & $0,00 \%$ & 1930 & 0 & $0,00 \%$ & 1840 & 1 & $0,05 \%$ \\
\hline Holandia & 24495 & 5 & $0,02 \%$ & 44970 & 11 & $0,02 \%$ & 20945 & 17 & $0,08 \%$ & 18210 & 4 & $0,02 \%$ \\
\hline Austria & 28035 & 18 & $0,06 \%$ & 88160 & 16 & $0,02 \%$ & 42255 & 65 & $0,15 \%$ & 24715 & 61 & $0,25 \%$ \\
\hline Polska & 8020 & 15 & $0,19 \%$ & 12190 & 21 & $0,17 \%$ & 12305 & 15 & $0,12 \%$ & 5045 & 0 & $0,00 \%$ \\
\hline Portugalia & 440 & $\mathrm{bd}$ & . & 895 & 0 & $0,00 \%$ & 1460 & $\mathrm{bd}$ & . & 1750 & 6 & $0,34 \%$ \\
\hline Rumunia & 1545 & 4 & $0,26 \%$ & 1260 & 6 & $0,48 \%$ & 1880 & 2 & $0,11 \%$ & 4815 & 11 & $0,23 \%$ \\
\hline Słowenia & 385 & 0 & $0,00 \%$ & 275 & 0 & $0,00 \%$ & 1310 & 3 & $0,23 \%$ & 1475 & 1 & $0,07 \%$ \\
\hline Słowacja & 330 & 0 & $0,00 \%$ & 330 & 0 & $0,00 \%$ & 145 & 1 & $0,69 \%$ & 160 & 3 & $1,88 \%$ \\
\hline Finlandia & 3620 & $\mathrm{bd}$ & . & 32345 & 2 & $0,01 \%$ & 5605 & 33 & $0,59 \%$ & 4990 & 6 & $0,12 \%$ \\
\hline Szwecja & 81180 & 20 & $0,02 \%$ & 162450 & 17 & $0,01 \%$ & 28790 & 67 & $0,23 \%$ & 26325 & 24 & $0,09 \%$ \\
\hline $\begin{array}{l}\text { Wielka } \\
\text { Brytania }\end{array}$ & 32785 & 0 & $0,00 \%$ & 40160 & 0 & $0,00 \%$ & 39735 & 0 & $0,00 \%$ & 34780 & 0 & $0,00 \%$ \\
\hline Islandia & 170 & 0 & $0,00 \%$ & 370 & 0 & $0,00 \%$ & 1125 & 0 & $0,00 \%$ & 1085 & 0 & $0,00 \%$ \\
\hline Lichtenstein & 65 & 0 & $0,00 \%$ & 150 & bd & . & 80 & 0 & $0,00 \%$ & 150 & 0 & $0,00 \%$ \\
\hline Norwegia & 11415 & 3 & $0,03 \%$ & 31110 & 5 & $0,02 \%$ & 3485 & 12 & $0,34 \%$ & 3520 & 1 & $0,03 \%$ \\
\hline Szwajcaria & 2355 & 39 & $1,66 \%$ & 39445 & 33 & $0,08 \%$ & 27140 & 81 & $0,30 \%$ & 18015 & 26 & $0,14 \%$ \\
\hline Suma & 640970 & 315 & $0,05 \%$ & 1393920 & 257 & $0,02 \%$ & 1292750 & 888 & $0,07 \%$ & 734985 & 1822 & $0,25 \%$ \\
\hline $\begin{array}{ll}\text { bd } & - \text { bra } \\
& - \text { bra }\end{array}$ & form & ub & inf & acji wis & I & ch & & & & & & \\
\hline
\end{tabular}

Źródło: opracowanie własne na podstawie danych dostępnych na portalu internetowym Europejskiego Urzędu Statystycznego z dnia 11.03.2019 r.

Wnioskować należy, że zmiany przepisów wprowadzone rozporządzeniem Dublin III doprowadziły do częstszego wykorzystywania klauzuli humanitarnej w procedurze dublińskiej, niż to miało miejsce na gruncie rozporządzenia Dublin II. Widoczny jest wzrost stosowania klauzuli w 2017 r. w Bułgarii, Grecji, Luksemburgu, na Malcie, w Austrii, na Słowacji. Najczęściej w okresie 2014-2017 klauzula wykorzystywana była w Grecji, Danii oraz na Słowacji, natomiast nie korzystały z niej w ogóle w prowadzonych postępowaniach: Estonia, Wielka Brytania, Islandia. 
Jak wynika z raportu Evaluation of the Implementation of the Dublin III Regulation, poszczególne państwa członkowskie w różny sposób rozpatrują składane wnioski o przejęcie z powodu klauzuli humanitarnej. Bułgaria, Rumunia i Szwecja poinformowały, że wnioski z art. 17 ust. 2 rozporządzenia Dublin III są prawie zawsze akceptowane. Władze greckie i czeskie zarzucały, że wysłane przez nie wnioski rzadko są przyjmowane ze względu na nieporozumienia dotyczące, po pierwsze, sposobu rozumienia zagadnienia "przyczyn humanitarnych”, po drugie, rozbieżności w stanowiskach odnośnie do tego, czy artykuł powinien być w rzeczywistości wykorzystywany do łączenia rodzin. Podobnie holenderskie organy wskazały, że niechętnie przyjmują wnioski z art. 17 ust. 2 rozporządzenia Dublin III i robią to tylko w wyjątkowych okolicznościach. W Polsce akceptowane są tylko wnioski złożone w oparciu o argument jedności rodziny i nie bierze się pod uwagę "powiązań kulturowych". Norwegia wskazała, że zwykle nie przyjmuje wniosków z art. 17 ust. 2 rozporządzenia Dublin III, ponieważ chce „unikać ludzi, którzy chcą ominąć regularne procedury migracji”. Podobnie niemieckie władze stwierdziły, że uważają, że klauzula jest wykorzystywana z powodów politycznych, szczególnie w państwach, które często ubiegają się o jej zastosowanie ${ }^{16}$.

Analiza powyższych danych $\mathrm{w}$ zestawieniu $\mathrm{z}$ orzecznictwem i przytoczonym stanowiskiem państw skłania do sformułowania wniosku, że klauzule dyskrecjonalne, choć wykorzystywane są stosunkowo rzadko, stanowią niezbędny element systemu dublińskiego, szczególnie z punktu widzenia ochrony praw wnioskodawców. Możliwość ich stosowania czyni system dubliński kompletnym, pozwala bowiem na dopasowanie regulacji systemu dublińskiego do pojawiających się od czasu do czasu sytuacji wyjątkowych. Wydaje się, że tak znikomy odsetek przypadków korzystania z klauzul oznacza, że wpływ na skuteczność i wydajność systemu dublińskiego nie jest zagrożona wydawanymi decyzjami dyskrecjonalnymi państw członkowskich. Szczególnie jest to widoczne wówczas, gdy spojrzy się na ogólną liczbę wniosków podlegających procedurze dublińskiej. Nie mniej, sprawy dotyczące tego zagadnienia stale są przedmiotem wydawanych przez TSUE orzeczeń, a tym samym są źródłem wątpliwości interpretacyjnych, prowadzących do spowolnienia procedury dublińskiej.

16 European Commission, Evaluation of the Implementation of the Dublin III Regulation DG Migration and Home Affairs. Final Report, oprac. E. Jurado i in., [Brussels] 2016, s. 35. 


\section{Klauzule dyskrecjonalne $\mathrm{w}$ procedowanym rozporządzeniu Dublin IV}

W dalszym ciągu trwają prace nad udoskonalaniem systemu dublińskiego, w tym także nad reformą wypracowanych klauzul dyskrecjonalnych. W dniu 5 czerwca 2016 r. Komisja Europejska przedstawiła wniosek dotyczący nowej wersji rozporządzenia, zwanego w literaturze rozporządzeniem Dublin IV ${ }^{17}$. Komisja zaproponowała dokonanie istotnych zmian w zakresie obydwu klauzul. Przepisy w zaproponowanej formie mają bardziej precyzyjny charakter względem obecnie obowiązujących, a nadto wydaje się, że możliwość skorzystania z każdej z klauzul została w znaczny sposób ograniczona.

W zakresie klauzuli suwerenności zaproponowano, by możliwe było skorzystanie $\mathrm{z}$ niej $\mathrm{w}$ drodze wyjątku od zasad ogólnych jedynie w przypadku, gdy żadnego państwa członkowskiego nie uznano za odpowiedzialne. Zaproponowano również ograniczenie przyczyn stosowania klauzuli jedynie do względów rodzinnych dotyczących dalszej rodziny, którzy nie wpisują się w krąg członków rodziny w rozumieniu rozporządzenia ${ }^{18}$.

Nadto proponuje się modyfikację sposobu stosowania klauzuli humanitarnej w ten sposób, że dopuszcza się możliwość skorzystania z niej tylko do tego etapu postępowania, na którym żadne państwo członkowskie nie zostało jeszcze uznane za odpowiedzialne ${ }^{19}$. Stosować klauzulę może zatem tylko państwo członkowskie, w którym złożony został wniosek. Wydaje się, iż jest to istotna zmiana, która eliminuje wiele wątpliwości interpretacyjnych, a także prowadzi do uniknięcia przedłużania postępowania wstępnego. Jako cel stosowania klauzuli wskazuje się jedynie połączenie wszystkich osób należących do rodziny.

Jak podkreśla B. Mikołajczyk, doświadczenia zdobyte w dobie kryzysu migracyjnego, w tym obserwacja nowych sytuacji rodzinnych

${ }_{17}$ Komisja Europejska, Wniosek rozporządzenie Parlamentu Europejskiego i Rady w sprawie ustanowienia kryteriów i mechanizmów ustalania państwa członkowskiego odpowiedzialnego za rozpatrzenie wniosku o udzielenie ochrony międzynarodowej złożonego w jednym z państw członkowskich przez obywatela państwa trzeciego lub bezpaństwowca (wersja przekształcona), Bruksela, 4.05.2016, COM(2016) 270 final, https:/ / eur-lex.europa.eu/legal-content/PL/TXT/ ?uri=CELEX\%3A52016PC0270\% 2801\% 29 [dostęp: 12.03.2019 r.], dalej: rozporządzenie Dublin IV.

18 Zob. F. Maiani, The Reform of the Dublin III Regulation, [Brussels] 2016, s. 32.

19 Zob. tamże. 
powstających w obozach dla uchodźców i podczas przemieszczania się wnioskodawców, skłoniły prawodawcę unijnego do zmiany - uwzględnionej w projekcie rozporządzenia Dublin IV - definicji członków rodziny poprzez rozszerzenie tego pojęcia o rodzeństwo wnioskodawcy i uwzględnienie więzi powstałych po opuszczeniu kraju pochodzenia, a przed dotarciem na terytorium państwa członkowskiego ${ }^{20}$.

Nadto komisja zaproponowała dalsze skrócenie terminu na udzielenie odpowiedzi w sprawie wniosku o przejęcie wniosku azylowego do rozpoznania do jednego miesiąca.

Nie bez znaczenia dla kształtu proponowanych ograniczeń są sugestie zgłaszane przez poszczególne państwa członkowskie. Jak wynika z raportu Evaluation of the Implementation of the Dublin III Regulation nie odnotowano wprawdzie istotnych problemów praktycznych z zastosowaniem klauzuli suwerenności, niemniej jednak z poszczególnych państw członkowskich docierają sygnały zaniepokojenia wynikające z procesu stosowania klauzul w obecnym kształcie. Zdaniem strony niemieckiej klauzula powinna być stosowana możliwie najbardziej restrykcyjnie, bowiem $\mathrm{w}$ innym przypadku powoływanie się na nią grozi podważeniem zasad systemu dublińskiego. Co więcej, Irlandia zasygnalizowała, że dotychczasowe reformy doprowadziły do zwiększenia sporów na poziomie krajowym. Prawnicy reprezentujący wnioskodawców traktują możliwość skorzystania z klauzuli suwerenności, jako uprawnienie podstawowe, co prowadzi w konsekwencji do zwiększenia liczby postepowań administracyjnych wywołanych składanymi odwołaniami ${ }^{21}$.

Ocena proponowanych zmian- jak podkreśla B. Mikołajczyk - dokonywana przez badaczy zagadnienia, organizacje pozarządowe, ekspertów ma jednak charakter krytyczny ${ }^{22}$. FrancescoMaiani zwraca szczególną uwagę na zagrożenie w postaci możliwej kolizji przyszłych przepisów dublińskich z Europejską Konwencją Praw Człowieka (EKPC). Zauważa on wprawdzie niewielkie dotychczasowe wykorzystanie klauzuli suwerenności, jednak dostrzega przy tym kluczowość tego elementu systemu dublińskiego, jako możliwości zrezygnowania z przeniesienia wnioskodawcy w obliczu zagrożenia w postaci naruszenia praw podstawowych.

20 Zob. B. Mikołajczyk, Mechanizm dubliński na rozdrożu - uwagi w związku z pracami nad rozporzadzeniem Dublin IV, Europejski Przegląd Sądowy 2018, nr 3, s. 7.

21 Zob. European Commission, Evaluation of the Implementation..., oprac. E. Jurado i in., s. 35.

22 Zob. B. Mikołajczyk, Mechanizm dubliński na rozdrożu..., s. 8. 
Nowe brzmienie przepisu o klauzuli suwerenności określa stosunki rodzinne $\mathrm{w}$ taki sposób, że nie jest możliwe pełne poszanowanie postanowień EKPC ${ }^{23}$.

Francesco Maiani podkreśla również, że proponowane ograniczenia stosowania klauzul mogą naruszać prawa osób małoletnich bez opieki. Chodzi w tym wypadku o możliwą kolizję wąskich kryteriów stosowania klauzul z zasadą nadrzędnego interesu dziecka.

Niezależnie nawet od kwestii dotyczących praw człowieka, F. Maiani zwraca uwagę na brak konieczności tak dalekiej modyfikacji klauzul dyskrecjonalnych. Komisja Europejska w złożonym projekcie motywuje taką decyzję ryzykiem podważenia skuteczności i trwałości systemu (motyw 21). Zdaniem F. Maiani jest to uzasadnienie o charakterze pozornym ${ }^{24}$, stąd też - zgodnie z tym stanowiskiem - klauzula suwerenności powinna zostać przeniesiona do rozporządzenia Dublin IV w formie niezmienionej względem obecnie obowiązującej wersji rozporządzenia dublińskiego ${ }^{25}$.

\section{Zakończenie}

Korzystanie z klauzul dyskrecjonalnych od początku ich istnienia zgodnie $\mathrm{z}$ zamiarem prawodawcy - stanowi wyjątek od stosowania ustalonych w procedurze dublińskiej kryteriów ustalania państwa odpowiedzialnego za rozpoznanie wniosku azylowego. Potwierdza to analiza danych statystycznych. Mimo że stale utrzymuje się niewielki co do zasady odsetek stosowania każdej z klauzul, przypadki ich zastosowania niejednokrotnie wiążą się z problemami interpretacyjnymi, co z kolei zobrazowane zostało stanowiskiem państw członkowskich i przykładami z orzecznictwa. Bez wątpienia państwa członkowskie dostrzegają w praktyce potrzebę korzystania ze swoich uprawnień dyskrecjonalnych i zauważają niedociągnięcia wiążące się z wykorzystywaniem klauzul, co starają się sygnalizować, choćby w postaci pytań prejudycjalnych. Stąd też przyczyną znikomego wykorzystywania klauzul dyskrecjonalnych może być obawa przed przedłużaniem procedury wstępnej wobec ciągle

\footnotetext{
${ }^{23}$ Zob. F. Maiani, The Reform of the Dublin III..., s. 40.

24 Zob. tamże.

25 Zob. tamże, s. 57.
} 
nieprecyzyjnych przepisów w tym zakresie. To z kolei stanowi zagrożenie nie tylko dla systemu dublińskiego, ale dla stabilności całego Wspólnego Europejskiego Systemu Azylowego, szczególnie w dobie kryzysu migracyjnego.

Dalsze doprecyzowywanie treści klauzul w procedowanym obecnie rozporządzeniu Dublin IV stanowi o wadze zagadnienia. Klauzule dyskrecjonalne są uznawane za instrument potrzebny $\mathrm{w}$ procedurze dublińskiej, jednak zgodnie z pierwotnie wyrażonym celem ich stosowania, możliwość dyskrecjonalnego kształtowania odpowiedzialności za rozpoznanie wniosku przez państwa członkowskie powinna być jedynie wyjątkiem od stosowania kryteriów dublińskich. Wydaje się, że organy prawodawcze dążą obecnie do takiego wyeliminowania wątpliwości interpretacyjnych w zakresie klauzul dyskrecjonalnych, które pozwoli na szybkie i jasne ich stosowanie, gdy zajdzie taka potrzeba. Przy tym precyzyjne ukształtowanie treści będzie ograniczało przypadki ewentualnych nadużyć w stosowaniu klauzul. Badacze zagadnienia słusznie jednak prognozują pojawienie się nowych problemów związanych z nadmiernym ograniczeniem możliwości wykorzystania klauzul.

Dodatkowo zmiany dążą do uniknięcia przedłużania postępowania wstępnego w razie korzystania z klauzul, co także znajduje odzwierciedlenie w projekcie rozporządzenia Dublin IV. Wyraz temu daje m.in. propozycja dalszego skrócenia terminu na odpowiedź na wezwanie do przejęcia wniosku do rozpoznania z powodu klauzuli humanitarnej.

Prace nad kształtem nowego systemu dublińskiego są w toku. Wszystkie proponowane zmiany, w tym także te dotyczące klauzul dyskrecjonalnych, są przedmiotem zagorzałych dyskusji. Ustalenie ostatecznej, równoważącej wszystkie stanowiska wersji nowego rozporządzenia stanowi niemałe wyzwanie dla ustawodawstwa UE. Przychylając się jednak do stanowiska wynikającego z literatury przedmiotu wskazać należy, że modyfikacje klauzul w obecnie proponowanej formie nie będą miały pozytywnego wpływu na podniesienie skuteczności systemu dublińskiego. Sugerowane zmiany nie prowadzą bowiem do wyjaśnienia mechanizmu stosowania klauzul, a do drastycznego ograniczenia ich wykorzystania. To z kolei doprowadzi do powstawania nowych trudności, choćby na polu poszanowania praw człowieka.

Słowa kluczowe: prawo azylowe UE, system dubliński, klauzule dyskrecjonalne 


\section{Bibliografia}

\section{Źródła}

\section{Akty prawa}

Konwencja wyznaczająca państwo odpowiedzialne za rozpatrywanie wniosków o azyl złożonych w jednym z Państw Członkowskich Wspólnot Europejskich, sporządzona w Dublinie dnia 15 czerwca 1990 r., Dz. U. z 2005 r. Nr 24, poz. 194.

Rozporządzenie Rady (WE) nr 343/2003 z dnia 18 lutego 2003 r. ustanawiające kryteria i mechanizmy określania Państwa Członkowskiego właściwego dla rozpatrywania wniosku o azyl, wniesionego w jednym z Państw Członkowskich przez obywatela państwa trzeciego, Dz. Urz. UE L 50 z 25.02.2003, s. 1-10; Dz. Urz. UE polskie wyd. spec.: rozdz. 19, t. 6, s. 109-118.

Rozporządzenie Parlamentu Europejskiego i Rady (UE) nr 604/2013 z dnia 26 czerwca 2013 r. w sprawie ustanowienia kryteriów i mechanizmów ustalania państwa członkowskiego odpowiedzialnego za rozpatrzenie wniosku o udzielenie ochrony międzynarodowej złożonego w jednym z państw członkowskich przez obywatela państwa trzeciego lub bezpaństwowca (wersja przekształcona), Dz. Urz. UE L 180 z 29.06.2013, s. 31-59.

\section{Dokumenty}

Commission of the Europan Communities, Proposal for a Council Regulation Establishing the Criteria and Mechanisms for Determining the Member State Responsiblefor Examining an Asylum Application Lodged in One of the Member States by a Third-country National, Brussels, 26.07.2001, COM(2001)447 final, http:/ / ec.europa.eu/transparency/regdoc/rep/1/2001/EN/1-2001-447EN-F1-1.pdf [dostęp: 11.03.2019 r.].

Commission of the European Communities, Revisiting the Dublin Convention: Developing Community Legislation for Determining which Member State is Responsible for Considering an Application for Asylum Submitted in One of the Member States, Brussels, 21.03.2000, SEC(2000)522 final, http:/ / www. statewatch.org/semdoc/assets/files/commission/SEC-2000-522.pdf [dostęp: 7.03.2019 r.].

European Council on Refugees and Exiles, Position on the Implementation of the Dublin Convention in the Light of Lessons Learned from the Implementation of the Schengen Convention, Brussels, 1.12.1997, https:/ / www.refworld.org/ pdfid/3df4d74f4.pdf [dostęp: 7.03.2019 r.].

Opinia Rzecznika Generalnego Paola Mengozziego przedstawiona w dniu 25 lipca 2018 r. Sprawa C-56/17BahtiyarFathi przeciwko Predsedatel na Darzhavnaagentsia za bezhantsite, ECLI:EU:C:2018:621, http://curia.europa.eu/juris/document/ 
document.jsf?text=klauzula*\%2Bsuwerenno $\% 25 \mathrm{C} 5 \% 259 \mathrm{Bci} \%$ 2Bhumanitarna *\&docid=204421\&pageIndex=0\&doclang=pl\&mode=req\&dir=\&occ=first\&pa $\mathrm{rt}=1 \& \mathrm{cid}=3303256 \#$ ctx1 [dostęp: 11.03 .2019 r.].

Opinia Rzecznika Generalnego Vericy Trstejnak przedstawiona w dniu 27 czerwca 2012 r. Sprawa C-241/11, ECLI:EU:C:2012:389, http:/ / curia.europa.eu/juris $/$ document $/$ document.jsf?text $=\&$ docid $=128441 \&$ pageIndex $=0 \&$ doclang $=p$ $1 \&$ mode=lst\&dir=\&occ $=$ first\&part=1\&cid=3600657 [dostęp: 11.03 .2019 r.].

Komisja Wspólnot Europejskich, Wniosek rozporządzenie Parlamentu Europejskiego i Rady ustanawiające kryteria i mechanizmy ustalania państwa członkowskiego odpowiedzialnego za rozpatrzenie wniosku o udzielenie ochrony międzynarodowej złożonego w jednym z państw członkowskich przez obywatela kraju trzeciego lub bezpaństwowca (wersja przekształcona), Bruksela, 3.12.2008, $\operatorname{KOM(2008)~} 820$ wersja ostateczna, https://eur-lex.europa.eu/ legal-content/PL/TXT/ ?qid=1550668055377\&uri=CELEX:52008PC0820 [dostęp: 20.02.2019 r.].

Komisja Europejska, Wniosek rozporządzenie Parlamentu Europejskiego i Rady w sprawie ustanowienia kryteriów i mechanizmów ustalania państwa członkowskiego odpowiedzialnego za rozpatrzenie wniosku o udzielenie ochrony międzynarodowej złożonego w jednym z państw członkowskich przez obywatela państwa trzeciego lub bezpaństwowca (wersja przekształcona), Bruksela, 4.05.2016, COM(2016) 270 final, https:/ / eur-lex.europa.eu/legal-content/PL/ TXT/?uri=CELEX\%3A52016PC0270\%2801\%29 [dostęp: 12.03.2019 r.].

\section{Orzecznictwo}

Wyrok TSUE z dnia 21 grudnia 2011 r. wydany w sprawach połączonych C-411/10 i C-493/10, ECLI:EU:C:2011:865.

Wyrok TSUE z dnia 6 listopada 2012 r. wydanym w sprawie C-245/11, ECLI:EU:C:2012:685.

\section{Literatura}

European Commission, Evaluation of the Implementation of the Dublin III Regulation DG Migration and Home Affairs. Final Report, oprac. E. Jurado i in., [Brussels] 2016.

Kowalczyk B., Kompetencje dyskrecjonalne państw w podstawach systemu dublińskiego, Acta Universitatis Wratislaviensis. Prawo 2015, nr 317.

Kowalewski P., Ekonomiczna kalkulacja, czyli dlaczego Niemcy tak chętnie przyjmuja uchodźców [online], serwis internetowy Forsal.pl, 14.12.2015 r., https:/ / forsal. pl/artykuly/910358, imigranci-w-niemczech-starzenie-sie-spoleczenstwa-demografia-uchodzcy.html [dostęp: 12.03 .2020 r.].

Maiani F., The Reform of the Dublin III Regulation, [Brussels] 2016.

Mikołajczyk B., Mechanizm dubliński na rozdrożu - uwagi w związku z pracami nad rozporzadzeniem Dublin IV, Europejski Przegląd Sądowy 2018, nr 3. 


\section{EVOLUTION OF DISCRETIONARY CLAUSES IN DUBLIN SYSTEM}

\section{Sum mary}

The article deals with the evolution of discretionary clauses - the sovereignty clause and humanitarian clause - in Dublin systemsince the beginning of its existence. It focuses on changes of regulations, caused by numerous interpretative doubts in several Member States, presents statistics on the use of clauses and finally explains the reasons for future changes. It refers to judgements of the Court of Justice and Eurostat database as well, which enables to explore how discretionary clauses have been incorporated into the whole Dublin system. As a result, the article shows that discretionary clauses are used only exceptionally by the Member States, but may lead to the overrunning of Dublin procedure due to imprecision. In turn, the EU legislator seeks to clarify the rules and limit the cases in which discretionary clauses replace the criteria arising from the Dublin III Regulation. While creating the article, the following methods were used: the descriptive, historical, legal and statistical analysis.

Key words: European asylum law, Dublin system, discretionary clauses

\section{ФОРМИРОВАНИЕ ДИСКРЕЦИОННЫХ ОГОВОРОК В ДУБЛИНСКОЙ СИСТЕМЕ}

\section{Резюме}

Статья касается процесса формирования дискреционных оговорок - оговорки о суверенитете и гуманитарной оговорки - в процессе определения государства, ответственного за рассмотрение заявления о предоставлении убежища. Содержит анализ вносимых с годами изменений в этой области. Изменения, внесенные до настоящего времени, а также запланированные на будущее, связаны с постоянной проблемой значительных сомнений в интерпретации в области обсуждаемых дискреционных полномочий государств. В исследовании приводится обзор статистических данных об использовании оговорок в отдельных государствах-членах, а также приводятся ссылки на решения Европейского суда, вынесенные в рамках поднятой проблематики. Автор пытается прояснить, как дискреционные оговорки влияют на Дублинскую систему, и в этом свете представляет направления будущих правовых усовершенствований, предложенных законодателем. Проведенное исследование показывает, что дискреционные оговорки используются только в исключительных случаях государствами-членами, однако, неточность нормативных положений приводит к тому, что возникновение этих, 
даже немногочисленных, случаев может привести к снижению эффективности Дублинской процедуры. В свою очередь, законодатель ЕС стремится уточнить правила и ограничить случаи, когда дискреционные оговорки заменяют критерии, вытекающие из Дублинского Регламента III. При написании статьи использовались следующие методы: описательный, исторический, правовой и статистический анализ.

Ключевые слова: Право убежища ЕС, Дублинская система, дискреционные оговорки 